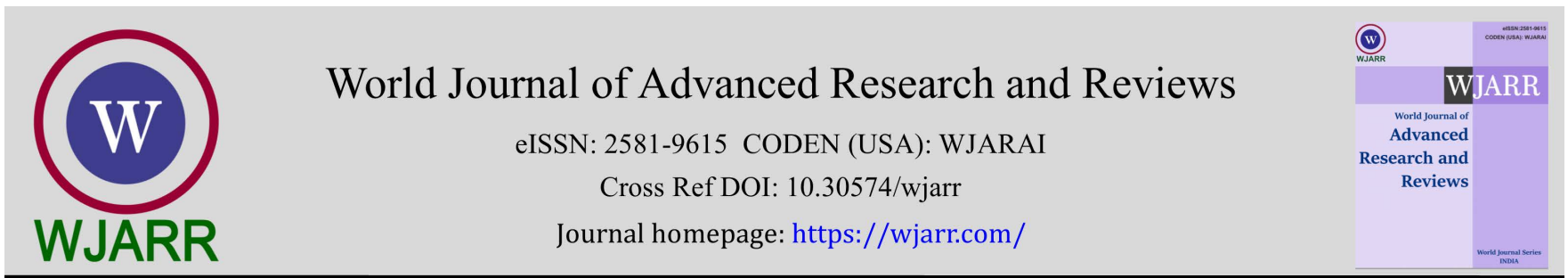

(RESEARCH ARTiClE)

Check for updates

\title{
Performance, blood chemistry, carcass and economic evaluation of sheep on dietary supplements of cabbage and carrot wastes
}

\author{
Michael Igbaekemen Okoruwa ${ }^{1,}{ }^{*}$, Emmanuel Eromosele Ikheloa ${ }^{2}$ and Debola Olusegun Oshibanjo ${ }^{3}$ \\ ${ }^{1}$ Department of Animal Science, Faculty of Agriculture, Ambrose Alli University, P.M.B. 14, Ekpoma, Edo State, Nigeria. \\ 2 Department of Agricultural economics and extension, Faculty of Agriculture, Ambrose Alli University, P.M.B. 14, Ekpoma, \\ Edo State, Nigeria. \\ ${ }^{3}$ Department of Animal Production, Faculty of Agriculture, University of Jos, Jos Plateau state, Nigeria.
}

World Journal of Advanced Research and Reviews, 2021, 12(02), 574-586

Publication history: Received on 15 October 2021; revised on 25 November 2021; accepted on 27 November 2021

Article DOI: https://doi.org/10.30574/wjarr.2021.12.2.0615

\begin{abstract}
The study was conducted to determine the effect of cabbage and carrot wastes supplementation on performance, blood chemistry, carcass and economic evaluation of sheep. Twenty four West African dwarf male sheep of about 8 - 9 months old with average initial weight of $9.00 \pm 0.94 \mathrm{~kg}$ were randomly allotted to four dietary treatments with six sheep per treatment, in a completely randomized design. The sheep received $60 \%$ guinea grass and $40 \%$ concentrate diet for TD 1 (control group), while $50 \%$ guinea grass and $40 \%$ concentrate diet with either $10 \%$ cabbage waste, $5 \%$ cabbage plus $5 \%$ carrot wastes or $10 \%$ carrot waste were for diets $\mathrm{TD}_{2}, \mathrm{TD}_{3}$ and $\mathrm{TD}_{4}$ respectively. The results showed that sheep on $\mathrm{TD}_{1}$ were significantly $(\mathrm{p}<0.05)$ higher in feed conversion ratio, creatinine, urea, rumen with intestine and total fixed cost. Diet $\mathrm{TD}_{2}$ was significantly $(\mathrm{p}<0.05)$ improved in daily weight gain, digestibility of dry matter, crude protein with fiber and nitrogen free extract, haemoglobin, packed cell volume, mean corpuscular haemoglobin, white blood cell, lymphocyte, neutrophil, total protein, albumin, glucose, dressing percentage, sale of sheep, total revenue and net profit. Red blood cell, cholesterol and triglyceride were increased significantly $(p<0.05)$ in $\mathrm{TD}_{3}$, while daily feed intake, digestibility of ash, feed cost and total variable cost were better in $\mathrm{TD}_{4}$. Meanwhile, no significant difference (p>0.05) was found in initial body weight, ether extract digestibility, mean corpuscular volume, mean corpuscular haemoglobin concentration, monocyte, eosinophil, basophil, globulin and some relative organs weight among sheep on treatments. It can be concluded that inclusion level of $10 \%$ cabbage waste as supplement to $50 \%$ guinea grass and $40 \%$ concentrate diet $\left(\mathrm{TD}_{2}\right)$ improved performance, health status and carcass indices of sheep with reduced cost that resulted in higher net profit.
\end{abstract}

Keywords: Crop-residues; Performance; Blood; Economic-analysis; Sheep

\section{Introduction}

Sheep have been recognised for their contributions to ruminant production in the tropics. They form significant proportion of small ruminants, as they constitute a very important part of livestock sector of the Nigerian agricultural economy. This was indicated by the estimated Nigerian ruminant livestock population of 34.5 million goats, 22.1 million sheep and 16.9 million cattle as noted by Lawal-Adebowale [1]. Emphatically, sheep have ability to survive over a prolong period of drought to produce prime carcass that contribute important share to the small holder economy. However, more attention has been paid to sheep production as their advantages are becoming more vital than ever before, particularly on their ability to produce multifaceted utility such as meat, milk, skin and wool. The important of sheep production in alleviating the low animal protein intake by man in developing nation has been emphasize in literature by Okoruwa [2].

${ }^{*}$ Corresponding author: MI Okoruwa

Department of Animal Science, Faculty of Agriculture, Ambrose Alli University, P.M.B. 14, Ekpoma, Edo State, Nigeria.

Copyright (c) 2021 Author(s) retain the copyright of this article. This article is published under the terms of the Creative Commons Attribution Liscense 4.0. 
Despite these afore-mentioned attributes, sheep farmers in Nigeria are still faced with various challenges, but the most important constraint that militates against their production is the nutritional needs of sheep. It was earlier reported by Al-Azazi [3] that nutrition remains one of the most important factors that determine the profitability of livestock venture. Hence, ruminants do better when energy and protein rich diets are strategically combined for feeding. The expensive nature of feedstuffs as a result of competition between man and livestock makes the combination difficult. Natural pastures which are the most abundant basal feed for sheep are sacred during the dry season, leading to changes in the composition of nutritive value and digestibility. As a result, ruminants are unable to meet their energy and protein requirements from the available poor quality feeds with subsequent marked weight loss and low productivity. This has caused the sheep farmers to search for alternative feeds that are less expensive, readily available with good nutritional potentials to improve the productivity of sheep [4].

Cabbage (Brassica oleracae var capitata L.) and carrot (Daucus carota) wastes are such alternative feeds that are now gaining recognition in ruminant nutrition. Cabbage is a green leafy vegetable that belong to the genus of Brazzica and family of Brassicace. It has a defined taste and crunchy texture with characteristics compact head in which the leave snug against other. The colours range from pale or light green to dark green. Cabbage has sulphur-containing secondary metabolites and bioactive compounds that associated with risk reduction of certain cancers [5]. Moreover, carrot belongs to the family of Umbelliferae and the only diverse coloured root crop grown for the edible purpose. It has different types of pigments in the form of carotenoide and flavonoids that impact rich pro-healthy antioxidant properties in it. Carrot possesses characteristics flavour due to the presences of terpenoids, polyacetylenes and sugar content that makes availability of carbohydrate to be relatively high. Its biological value credited it with good medical properties and alkaline elements that purify and revitalize the blood. However, cabbage and carrot are fresh, edible and succulent parts of herbaceous plants which contain appreciable amount of dietary fibre, vitamins and minerals but minimum amount of protein. They are ranked among the top twenty vegetable crops grown world-wide by Food and Agricultural Organisation [6]. Due to this abundant production and frequent usage of these cabbage and carrot, their wastes are now constantly discarded and accumulated in public areas leading to environmental hazards. Thus, higher percentage of these wastes can be used as alternative feeds to supplement forages during feed shortage to minimize environmental nuisance and feed cost. The, study was therefore aim to investigate the effect of dietary supplementation of cabbage and carrot wastes on performance, blood chemistry, carcass and economic evaluation of sheep.

\section{Material and methods}

\subsection{Experimental Site}

The experiment was carried out at the sheep and goat unit of the Livestock Teaching and Research Farm of Ambrose Alli University, Ekpoma, Nigeria, The site is located on longitude $6.09^{\circ} \mathrm{E}$ and latitude $6.42^{\circ} \mathrm{N}$ of humid climatic zone of south-south Nigeria. The relative humidity of the area was about $78 \%$., while the average annual rainfall and temperature were about $1556 \mathrm{~mm}$ and $31^{\circ} \mathrm{C}$ respectively.

\subsection{Experimental Diets}

Fresh cabbage and carrot wastes (leaves stem and root) were collected every two days from different strategic areas of their selling points within Ekpoma. They were kept separately, cleaned and chopped into smaller sizes of about $5 \mathrm{~cm}$ of length. Guinea grass was obtained within the farm land, wilted overnight and chopped to lengths of about 5 to $6 \mathrm{~cm}$ before used. The concentrate diet offered in this study was a mixture of 38\% wheat offal, 30\% brewery dried grain, $28 \%$ shell/broken groundnut, $2.50 \%$ bone meal, $1.00 \%$ vitamin premix and $0.50 \%$ salt. Thus, the compared experimental diets were; $\mathrm{TD}_{1}$ that contained $60 \%$ guinea grass with neither cabbage waste nor carrot waste that served as the control group, $\mathrm{TD}_{2}$ consisted $50 \%$ guinea grass with $10 \%$ cabbage waste, $\mathrm{TD}_{3}$ comprised $50 \%$ guinea grass with $5 \%$ cabbage waste and $5 \%$ carrot waste and $\mathrm{TD}_{4}$ comprised $50 \%$ guinea grass with $10 \%$ carrot waste. However, $40 \%$ concentrate mixture was added to all the experimental diets irrespective of the treatment.

\subsection{Animals, design and management}

In this study, about 8 to 9 months old of twenty four West African dwarf male sheep were sourced from local market within Ekpoma and transported to the experimental site. They were quarantined for the period of one week and allowed to adapt to confinement in individual pens during the preliminary period of five days. Sheep were subjected to routine vaccination program against infectious diseases. Their bodies were also sprayed with a suitable pesticide (Diazione) to take care of the ecto-parasite infestation and $1.5 \mathrm{ml}$ Oxytetracycline was provided intravenous for three consecutive days to treat the sheep from possible respiratory diseases while $250 \mathrm{mg}$ of albendazole were administered through drenching gun to deworm the animals. 
At the end of this adjustment period, the sheep were labeled with ear tag, weighed and the average initial weight was recorded before they were randomly assigned to the treatment diets. The feeding trial was a completely randomized design, consisting of one control and three test treatment diets with each treatment containing three replicates of two sheep making a total of six sheep that were randomly assigned to each treatment. Then, they were housed in individually clean and hygienic semi-open pens. Each sheep was provided with feeder and watering trough. Consequently, the average initial body weight of the sheep was taken as $9.00 \pm 0.94 \mathrm{~kg}$ before sheep commenced their treatment diets that were twice daily at about 8:00am and 4:00pm. The quantity of guinea grass, cabbage and carrot wastes with concentrate supplied per sheep per day was calculated on the basis of $5 \%$ of their body weight. Guinea grass with either of the fruit waste or their mixture was offered separately from the concentrate diet. The trial was conducted for 90 days exclusive the 15 days adaptation period.

\subsection{Procedures and Measurements}

\subsubsection{Growth and Digestibility}

The difference between daily amount of feed offered to each sheep and leftover was used to determine the total and average daily feed intakes. After the initial body weight of sheep were weighed and recorded at the commencement of the trial, measurement was taken subsequently once every week for the assessment of change in growth rate using a mobile metallic weighing scale prior to morning feeding. A standard $100 \mathrm{~kg}$ salter scale was mounted on the weighing crate. The difference between the final and initial body weight was used to determine the total body weight gain, while the average daily weight gain was estimated through the relationship between the total weight gain and total number of days for the feeding trial. However, feed conversion ratio was calculated by dividing average daily feed intake with body weight gain.

Digestion trial was conducted after 70 days growth study to determine apparent nutrient digestion of the diets. Three sheep with similar body weight were taken from each treatment group and housed separately in individual metabolic cages designed for separate collection of faeces and urine. Feed offered, leftover and voided faeces were collected and recorded daily for the duration of 7days, after a 7-day of adjustment period to the cage. A sub-sample of about $10 \%$ of the total feacal output was bulked, thoroughly mixed and pooled for each sheep before stored in plastic container in the freezer $(-20 \%)$ for later analysis. Apparent digestibility (AD) of the diet was calculated for dry matter, crude protein, crude fiber, ether extract, ash, nitrogen free extract, neutral and acid detergent fiber of each treatment diet using the equation proposed by McDonald and Edward [7].

$$
\mathrm{AD} \%=\frac{\text { Total amount of nutrients in feed }- \text { total amount of nutrients in faeces }}{\text { Total amount of nutrients in feed }} \times 100
$$

\subsubsection{Blood collection and analysis}

Blood was collected from each sheep at the end of the experiment before carcass evaluation. Blood sample was taken from the jugular venipucture using disposable heparinised syringes into sterilized evacuated collection tubes before morning feeding. The first $5 \mathrm{ml}$ of the blood was drawn into ethylene diamine tratraacetic acid (EDTA) anticoagulant bottles for the determination of haematological parameters. These includes, haemoglobin (Hb) concentration that was determined by using cyano-methaemoglobin method, packed cell volume (PCV) was obtained as micro haematocrit with 75 x 16mm capillary tubes filled with blood and centrifuged at 3000rpm for 5minutes. Red blood cell (RBC) count was done in a haemocytometer chamber with Natt and Herdrics diluents to obtain a 1:200 blood dilution according to the standard methods of reported by Coles [8]. The numbers of lymphocyte, neutrophil, monocyte, eosinophil and basophil counts were determined and leucocyte was estimated as total white blood cell (WBC) x 200. The erythrocytic indices, mean corpuscular volume (MCV), mean corpuscular haemoglobin (MCH) and mean corpuscular haemoglobin concentration (MCHC) were computed as described by Jain [9].

The second $5 \mathrm{ml}$ sub-sample was taken into anti-coagulant free plastic tubes and gently inverted a couple of times to allow coagulation at room temperature. They were later centrifuged for 15 minutes at $890 \mathrm{xg}$ at $4^{\circ} \mathrm{C}$ and maintained for 8 hours in refrigerator at $4^{\circ} \mathrm{C}$ for separation of supernatant serum. The biochemical constituents of the serum samples estimated include total protein and albumin that were analyzed by using commercial kits (Biuret method, chemelex, SA Barcelona), Urea in the serum samples were estimated using the diacetylmonoxime method, creatinine was obtained by the Jaffe reaction method while blood glucose, cholesterol and triglycerides were obtained by enzymatic colorimetric test. The analysis followed the procedures described by Kim et al. [10], while globulin was calculated by subtracting albumin from total protein serum. 


\subsubsection{Carcass Evaluation}

At the end of experimental period before termination, three sheep from each treatment were selected, fasted overnight, weighed to obtained slaughter weight, stunned and slaughtered for carcass evaluation. After complete bleeding by hanging, the sheep in a head down position, carcass was skinned, eviscerated and dressed out. The weights of the following carcass parts were then recorded; head, neck, skin, thorax, rack, heart, lung, trachea, liver, gall bladder, spleen, testis, kidneys, lumber, trotters, rumen, small and large intestines. Hot carcass weight (HCW) was determined after the removal of the head, skin, internal tract and internal organs [11]. Dressing percentage was calculated as the proportion of hot carcass weight over empty body weight multiply by 100 .

Empty body weight $=$ Body weight after complete bleeding and removing of digestive tract.

\subsubsection{Economic efficiency measures}

The important economic efficiency indices investigated are; cost, revenue and net profits. The cost parameters were, total fixed cost (TFC), total variable cost (TVC), and total cost (TC). Total fixed cost includes labour, cost of purchased sheep, transportation with depreciation of equipment and pens that were calculated per animal for each group. Pens were depreciated over 10 years while the equipment over 4 years. Thus, these parameters were considered fixed costs for each of the animal used in the study. Total variable cost consists of utility costs (water, communication and electricity), veterinary service/drugs and cost of feed ingredients with cost of carrot and cabbage wastes. The cost price was estimated in Nigerian naira over the cost of the experiment. Total cost was calculated as the sum of total fixed cost and total variable cost [4]. However, total revenue (TR) were values of final body weight and litter sale, while net profit (NP) was computed by finding the difference between the total revenue and total cost.

Thus, formal for calculations were; TC = TFC + TVC

$\mathrm{TR}=$ Quantity $\mathrm{x}$ Price

$\mathrm{NP}=\mathrm{TR}--\mathrm{TC}$, Thus, $\mathrm{TR}-(\mathrm{TFC}+\mathrm{TVC})$

\subsubsection{Chemical Analysis of the Feeds}

The proximate analysis of feeds, treatment diets and faecal samples were conducted according to the standard methods of [12]. The samples were dried overnight at $105^{\circ} \mathrm{C}$ in a forced - air oven to determine the dry matter (DM) content, before milled to pass through a $1 \mathrm{~mm}$ screen in a Willey mill for other analysis. Ash was determined by combusting the samples at $550^{\circ} \mathrm{C}$ for 5 hours. Nitrogen was extracted with kjeldahl method and then the crude protein was calculated as nitrogen x 6.25 [12]. The determination of ether extract was assessed by taking 1gram of the dried sample which was folded in a filter paper and placed in soxhlet apparatus. It was then refluxed 30-40 times using petroleum benzene (boiling point $60-80^{\circ} \mathrm{C}$ ) until all the fat from the sample was then transferred to desiccators and allowed to cool overnight and reweighed using sensitive balance. The content of crude fibre, sequential neutral detergent fiber and acid detergent fiber were determined using Tecator Line (FT122 Fibertee TM) according to the method described by [13]. All samples were analysed in duplicates at the Animal science Laboratory of Faculty of Agriculture, Ambrose Alli University, Ekpoma.

\subsection{Statistical Analysis}

Data obtained from the study were subjected to analysis of variance (ANOVA) using the general linear model (GLM) procedure of SAS [14] to determine the effects of dietary treatments on various parameters studied. When significant differences were observed among treatments means, they were separated by Duncan's multiple range test. Comparisons with $\mathrm{p}<0.05$ were considered significant and all statements of statistical differences were based on this level unless noted otherwise. The linear model that explained the statistical tools used for data analysis were as follows

$Y i j=U+A i+e i j k$

Where;

Yij = the observed jth variable in the ith treatment diets (fixed factor)

$\mathrm{G}=$ overall means of the observed variable

$\mathrm{Ai}=$ effect due to ith treatment diets 
eij $=$ effect of random residual error

\section{Results}

The chemical composition of feed ingredients examined (Table 1), showed that concentrate ration (CR) recorded the highest content of dry matter and crude protein but relatively lower in crude fibre values as compared with guinea grass (GG) that had highest value. Cabbage and carrot wastes (CBW and CRW) marked lower values in ether extract (EE) but higher in ash content than values recorded in CR and GG. However, CBW and GG showed lower values in nitrogen free extract than CRW and CR. On the other hand, crude fibre fractions (acid and neutral detergent fibre) had relative higher remarkable difference between CBW and GG as compared with CBW and CR.

Table 1Chemical composition (\% DM) of feed ingredients

\begin{tabular}{|l|c|c|c|c|}
\hline \multirow{2}{*}{ Nutrients } & \multicolumn{4}{|c|}{ Feed Ingredients } \\
\cline { 2 - 5 } & CBW & CRW & GG & CR \\
\hline Dry matter & 79,69 & 70.52 & 89.93 & 90.62 \\
\hline Crude protein & 12.05 & 6.49 & 8.86 & 26.03 \\
\hline Crude fibre & 27.85 & 16.08 & 34.78 & 9.12 \\
\hline Ether extract & 0.98 & 2.52 & 3.07 & 5.26 \\
\hline Ash & 9.66 & 7.46 & 6.09 & 4.32 \\
\hline Nitrogen free extract & 33.15 & 45.97 & 38.43 & 45.89 \\
\hline Neutral detergent fibre & 53.78 & 35.95 & 72.66 & 26.62 \\
\hline Acid detergent fibre & 32.09 & 19.03 & 49.37 & 13.07 \\
\hline
\end{tabular}

Dry matter was highest in $\mathrm{TD}_{1}$ and lowest in $\mathrm{TD}_{4}$ as indicated in the chemical composition of the experimental diets (Table 2). Diet with solely CBW inclusion recorded higher content of crude protein and ash values as compared with control group and diets with CBW and CRW or solely CRW inclusion. The percentage of crude fibre and its fractions showed higher values in diet $\mathrm{TD}_{1}$ than the values registered in diets $\mathrm{TD}_{2}, \mathrm{TD}_{3}$ and $\mathrm{TD}_{4}$ respectively. Moreover, ether extract was generally low in diets with no much remarkable difference between treatments. Nitrogen free extract had highest content in $\mathrm{TD}_{1}$, followed by $\mathrm{TD}_{2}$ before the values obtained in diets $\mathrm{TD}_{1}$ and $\mathrm{TD}_{1}$ respectively.

Table 2 Chemical composition (\% DM) of experimental diets of sheep

\begin{tabular}{|c|c|c|c|c|}
\hline \multirow[t]{2}{*}{ Nutrients } & \multicolumn{4}{|c|}{ Treatment Diets } \\
\hline & TD $_{1}$ & $\mathbf{T D}_{2}$ & TD $_{3}$ & TD $_{4}$ \\
\hline Dry matter & 87.45 & 85.97 & 82.62 & 80.99 \\
\hline Crude protein & 15.29 & 15.57 & 15.30 & 15.02 \\
\hline Crude fibre & 26.52 & 24.83 & 24.24 & 23.65 \\
\hline Ether extract & 3.95 & 3.73 & 3.81 & 3.89 \\
\hline Ash & 5.38 & 5.74 & 5.63 & 5.52 \\
\hline Nitrogen free extract & 38.31 & 37.10 & 34.64 & 33.91 \\
\hline Neutral detergent fibre & 54.25 & 52.36 & 51.47 & 50.58 \\
\hline Acid detergent fibre & 34.85 & 33.13 & 32.48 & 31.82 \\
\hline
\end{tabular}


Differences were observed in the rate of total and daily feed consumption of sheep (Table3). Animals onTD 3 and $\mathrm{TD}_{4}$ were noted to have higher significant $(\mathrm{p}<0.05)$ intake of feeds than those found on $\mathrm{TD}_{1}$ and $\mathrm{TD}_{2 .}$. The initial body weight distribution of sheep appeared to be similar, hence it was not significantly ( $p>0.05)$ influenced. Furthermore, final body weight was significantly $(\mathrm{p}<0.05)$ highest in sheep on diets supplemented with solely cabbage waste $\left(\mathrm{TD}_{2}\right)$ and mixture of cabbage and carrot wastes $\left(\mathrm{TD}_{3}\right)$, followed by solely carrot waste $\left(\mathrm{TD}_{4}\right)$ and control diet $\left(\mathrm{TD}_{1}\right)$. Total and daily weight gains showed similar pattern of variation as noticed in final body weight. Thus, the heaviest body weight of sheep was recorded on $\mathrm{TD}_{2}$ as compared with control group that had the lightest weight gained. Feed conversion ratio value was significantly $(\mathrm{p}<0.05)$ lower in diets $\mathrm{TD}_{2}$, and $\mathrm{TD}_{3}$ than $\mathrm{TD}_{1}$ and $\mathrm{TD}_{4}$.

Nutrient digestibility parameters were significantly $(\mathrm{p}<0.05)$ affected by treatment diets as indicted in Table 3 . Digestibility percentage of dry matter, crude protein and nitrogen free extract were improved when cabbage waste or cabbage and carrot wastes were included in diets than diet with solely carrot waste and control group. Digestibility of crude fibre and its fractions (neutral and acid detergent fibres) followed almost the same trends as noted in crude protein. However, ash was best digested by sheep on diets $\mathrm{TD}_{3}$ and $\mathrm{TD}_{4}$ while ether extract digestibility was not significantly $(p>0.05)$ enhanced in the control group and the test diets.

Table 3 Growth performance and nutrient digestibility of sheep fed diets containing varying levels of cabbage and carrot wastes

\begin{tabular}{|c|c|c|c|c|c|}
\hline \multirow[t]{2}{*}{ Parameters } & \multicolumn{5}{|c|}{ Treatment Diets } \\
\hline & TD $_{1}$ & $\mathbf{T D}_{2}$ & $\mathbf{T D}_{3}$ & TD $_{4}$ & SEM \pm \\
\hline Total feed intake (kg) & $21.41^{b}$ & $20.91^{b}$ & $22.39^{a}$ & $22.82^{\mathrm{a}}$ & 0.07 \\
\hline Daily feed intake (g) & $305.89 \mathrm{~b}$ & $299.76^{b}$ & $310,58^{a}$ & $325.92^{\mathrm{a}}$ & 1.63 \\
\hline Initial body weight (kg) & 9.99 & 9.89 & 9.92 & 9.96 & 0.02 \\
\hline Finial body weight (kg) & $12.83^{\mathrm{b}}$ & $13.46^{\mathrm{a}}$ & $13.21^{\mathrm{a}}$ & $13.09^{a}$ & 0.25 \\
\hline Total body weight gain (kg) & $2.84^{\mathrm{b}}$ & $3.57^{\mathrm{a}}$ & $3.29^{a}$ & $3.13^{\mathrm{a}}$ & 0.04 \\
\hline Daily body weight gain (g) & $40.57^{c}$ & $51.00^{\mathrm{a}}$ & $47.00^{\mathrm{b}}$ & $44.71^{\mathrm{b}}$ & 0.98 \\
\hline Feed conversion ratio & $7.54^{\mathrm{a}}$ & $5.86^{c}$ & $6.80^{\mathrm{b}}$ & $7.29^{a}$ & 0.31 \\
\hline \multicolumn{6}{|l|}{ Nutrient Digestibility (\%) } \\
\hline Dry matter & $70.01^{\mathrm{c}}$ & $75.63^{\mathrm{a}}$ & $73.44^{\mathrm{b}}$ & $70.98^{c}$ & 0.59 \\
\hline Crude protein & $68.95^{b}$ & $72.42^{\mathrm{a}}$ & $70.08^{\mathrm{a}}$ & $67.66^{b}$ & 0.86 \\
\hline Crude fibre & $68.08^{b}$ & $71.75^{\mathrm{a}}$ & $69.90^{\mathrm{ab}}$ & $67.45^{b}$ & 0.64 \\
\hline Ether extract & 61.03 & 60.37 & 60.01 & 61.15 & 0.02 \\
\hline Ash & $52.46^{c}$ & $64.67^{b}$ & $66.85^{\mathrm{a}}$ & $67.70^{\mathrm{a}}$ & 0.35 \\
\hline Nitrogen free extract & $60 ; 94^{c}$ & $68.98^{\mathrm{a}}$ & $66.26^{\mathrm{b}}$ & $62.85^{c}$ & 0.88 \\
\hline Neutral detergent fibre & $54.88^{c}$ & $67.59^{a}$ & $64.78^{a}$ & $59.86^{b}$ & 0.97 \\
\hline Acid detergent fibre & $14.69^{c}$ & $23.07^{\mathrm{a}}$ & $21.03^{\mathrm{a}}$ & $18.62^{b}$ & 0.12 \\
\hline
\end{tabular}

The concentration of haemoglobin, packed cell volume, red blood cell and mean corpuscular haemoglobin were significantly $(\mathrm{p}<0.05)$ improved in sheep on test diets as against the control group (Table 4). White blood cell and its counts such as lymphocyte and neutrophil were also significantly $(\mathrm{p}<0.05)$ affected by treatment diets, with sheep on cabbage and carrot wastes had higher values than diet with no inclusion. However, no significant effect ( $p>0.05)$ was registered in proportion of mean corpuscular volume, mean corpuscular haemoglobin concentration, monocyte, eosinophil and basophil.

Serum total protein was significantly $(\mathrm{p}<0.05)$ increased in test diets than the control diet in the study. Albumin, glucose, cholesterol and triglycerides had similar significant $(\mathrm{p}<0.05)$ trends of variation as serum total protein. Meanwhile, it is 
worthy to know that significant ( $p>0.05$ ) difference did not occur in serum globulin concentration in this present study. The remarkable difference observed in creatinine and urea was higher $(\mathrm{p}<0.05)$ in control diet as compared with test diets.

Table 4 Haematological and serum biochemical indices of sheep fed experimental diets

\begin{tabular}{|c|c|c|c|c|c|}
\hline \multirow[t]{2}{*}{ Parameters } & \multicolumn{5}{|c|}{ Treatment Diets } \\
\hline & TD $_{1}$ & $\mathbf{T D}_{2}$ & $\mathrm{TD}_{3}$ & $\mathrm{TD}_{4}$ & SEM \pm \\
\hline Haemoglobin (g/dl) & $9.46^{b}$ & $10.09^{a}$ & $10.04^{\mathrm{a}}$ & $9.89^{\mathrm{b}}$ & 0.27 \\
\hline Packed cell volume (\%) & $24.29^{b}$ & $25.96^{\mathrm{a}}$ & $25.63^{\mathrm{a}}$ & $24.95^{b}$ & 0.08 \\
\hline Red blood cell $\left(\mathrm{x} 10^{6} / \mathrm{ml}\right)$ & $8.99^{b}$ & $9.97^{\mathrm{a}}$ & $10.04^{\mathrm{a}}$ & $9.82^{\mathrm{a}}$ & 0.15 \\
\hline MCV (fl) & 34.08 & 34.92 & 34.98 & 34.65 & 0.64 \\
\hline MCH (pg) & $8.98^{\mathrm{b}}$ & $10.42^{\mathrm{a}}$ & $10.35^{\mathrm{a}}$ & $10.29 \mathrm{a}$ & 0.37 \\
\hline MCHC (\%) & 31.99 & 32.06 & 32.04 & 32.02 & 0.74 \\
\hline White blood cell $\left(\mathrm{x} 10^{6} / \mathrm{ml}\right)$ & $8.69^{\mathrm{b}}$ & $10.92^{\mathrm{a}}$ & $10.83^{\mathrm{a}}$ & $10.54^{\mathrm{a}}$ & 0.92 \\
\hline Lymphocyte (\%) & $55.83^{\mathrm{b}}$ & $65.48^{\mathrm{a}}$ & $63.66^{\mathrm{a}}$ & $58.97 \mathrm{~b}$ & 0.85 \\
\hline Neutrophil (\%) & $24.06^{c}$ & $33.67^{a}$ & $31.99^{a}$ & $29.75^{b}$ & 0.69 \\
\hline Monocyte (\%) & 1.96 & 2.24 & 2.53 & 2.12 & 0.02 \\
\hline Eosinophil (\%) & 4.69 & 4.27 & 4.38 & 4.69 & 0.03 \\
\hline Basophil (\%) & 2.00 & 1,77 & 1.87 & 1.98 & 0.10 \\
\hline \multicolumn{6}{|l|}{ Serum biochemistry } \\
\hline Total protein (g/dl) & $6.78^{b}$ & $7.71^{\mathrm{a}}$ & $7.62^{\mathrm{a}}$ & $7.47^{\mathrm{a}}$ & 0.23 \\
\hline Albumin (g/dl) & $2.97 \mathrm{~b}$ & $3.83^{\mathrm{a}}$ & $3.70^{a}$ & $3.51^{\mathrm{a}}$ & 0.69 \\
\hline Globulin (g/dl) & 3.81 & 3.88 & 3.92 & 3.96 & 0.34 \\
\hline Glucose (mg/dl) & $61.94^{b}$ & $65.73^{\mathrm{a}}$ & $67.58^{a}$ & $68.01^{\mathrm{a}}$ & 0.92 \\
\hline Cholesterol (mg/dl) & $40.46^{c}$ & $55.67^{b}$ & $66.85^{\mathrm{a}}$ & $47.70^{\mathrm{bc}}$ & 0.95 \\
\hline Triglycerides (mg/dl) & $20.44^{\mathrm{b}}$ & $21.72^{\mathrm{a}}$ & $22.94^{\mathrm{a}}$ & $21.89^{a}$ & 0.81 \\
\hline Creatinine (mg/dl) & $1.07^{\mathrm{a}}$ & $0.92^{\mathrm{b}}$ & $0.93^{\mathrm{b}}$ & $0.92^{\mathrm{b}}$ & 0.05 \\
\hline Urea (mg/dl) & $13.91^{\mathrm{a}}$ & $9.86^{\mathrm{b}}$ & $10.23^{b}$ & $10.42^{b}$ & 0.47 \\
\hline
\end{tabular}

$\mathrm{SEM}=$ Standard error of mean, $\mathrm{MCV}=$ Mean corpuscular volume, $\mathrm{MCH}=$ Mean corpuscular haemoglobin, $\mathrm{MCHC}=$ Mean corpuscular haemoglobin concentration

Slaughter with hot carcass weight, dressing percentage, neck, rack and lumber as noted in Table 5 were significantly $(p<0.05)$ higher in weights for sheep on diets with cabbage waste inclusion than other dietary treatments. It is worthy pointing out that thorax, heart, liver and kidneys were not influenced significantly $(p>0.05)$ by treatment diets.

Edible offal of sheep (Table, 6) such as head, lungs, testis and skin were significantly $(\mathrm{p}<0.05)$ affected by treatment diets, with sheep on test diets recorded higher values as compared with control group. Diet with neither cabbage nor carrot waste supplement was considerably higher in rumen, small and large intestine values than the test diets. However, differences ( $p>0.05)$ were not registered in trachea, blood, gall bladder, spleen and trotters in the treatments. 
Table 5 Carcass characteristics of sheep fed diets containing varying levels of cabbage and carrot wastes

\begin{tabular}{|c|c|c|c|c|c|}
\hline \multirow[t]{2}{*}{ Carcass components (kg) } & \multicolumn{5}{|c|}{ Treatment Diets } \\
\hline & TD $_{1}$ & $\mathbf{T D}_{2}$ & $\mathrm{TD}_{3}$ & $\mathrm{TD}_{4}$ & $\operatorname{SEM} \pm$ \\
\hline Slaughter weight & $12.79^{b}$ & $13.36^{\mathrm{a}}$ & $13.11^{\mathrm{a}}$ & $12.99 \mathrm{~b}$ & 0.14 \\
\hline Hot carcass weight & $4.96^{\mathrm{c}}$ & $6.73^{\mathrm{a}}$ & $6.19^{\mathrm{a}}$ & $5.86^{\mathrm{b}}$ & 0.09 \\
\hline Dressing (\%) & $44.25^{b}$ & $55.03^{\mathrm{a}}$ & $51.54^{\mathrm{a}}$ & $49.66^{\mathrm{ab}}$ & 0.96 \\
\hline Neck & $0.38^{\mathrm{b}}$ & $0.50^{\mathrm{a}}$ & $0.47^{\mathrm{a}}$ & $0.43^{\mathrm{a}}$ & 0.04 \\
\hline Thorax & 1.29 & 1.37 & 1.34 & 1.31 & 0.05 \\
\hline Rack & $0.10^{\mathrm{b}}$ & $0.20^{\mathrm{a}}$ & $0.18^{\mathrm{b}}$ & $0.15^{\mathrm{b}}$ & 0.06 \\
\hline Heart & 0.05 & 0.09 & 0.09 & 0.07 & 0.04 \\
\hline Lumber & $0.32^{\mathrm{b}}$ & $0.41^{\mathrm{a}}$ & $0.39^{b}$ & $0.37 \mathrm{~b}$ & 0.10 \\
\hline Liver & 0.21 & 0.24 & 0.25 & 0.24 & 0.03 \\
\hline Kidneys & 0.01 & 0.03 & 0.02 & 0.02 & 0.01 \\
\hline
\end{tabular}

Table 6 Edible offal of carcass traits of sheep fed diets supplemented with cabbage and carrot wastes

\begin{tabular}{|l|c|c|c|c|c|}
\hline \multirow{2}{*}{ Parameters } & \multicolumn{5}{|c|}{ Treatment Diets } \\
\cline { 2 - 6 } & $\mathbf{T D}_{\mathbf{1}}$ & $\mathbf{T D}_{\mathbf{2}}$ & $\mathbf{T D}_{\mathbf{3}}$ & $\mathbf{T D}_{\mathbf{4}}$ & $\mathbf{S E M} \mathbf{\pm}^{\mathbf{3}}$ \\
\hline Head & $3.42^{\mathrm{b}}$ & $4.13^{\mathrm{a}}$ & $4.06^{\mathrm{a}}$ & $3.95^{\mathrm{b}}$ & 0.12 \\
\hline Lung & $0.62^{\mathrm{c}}$ & $0.95^{\mathrm{a}}$ & $0.93^{\mathrm{a}}$ & $0.87^{\mathrm{b}}$ & 1.07 \\
\hline Testis & $0.48^{\mathrm{c}}$ & $0.60^{\mathrm{a}}$ & $0.58^{\mathrm{a}}$ & $0.51^{\mathrm{ab}}$ & 0.14 \\
\hline Skin & $6.79^{\mathrm{b}}$ & $7.04^{\mathrm{b}}$ & $7.01^{\mathrm{a}}$ & $6.92^{\mathrm{b}}$ & 0.21 \\
\hline Trachea & 0.58 & 0.62 & 0.61 & 0.60 & 0.02 \\
\hline Blood & 2.34 & 2.24 & 2.27 & 2.29 & 0.07 \\
\hline Gall bladder & 0.16 & 0.20 & 0.20 & 0.19 & 0.04 \\
\hline Spleen & 0.04 & 0.05 & 0.03 & 0.06 & 0.01 \\
\hline Trotters & 0.48 & 0.52 & 0.51 & 0.49 & 0.03 \\
\hline Rumen & $2.60^{\mathrm{a}}$ & $1.98^{\mathrm{b}}$ & $1.95^{\mathrm{b}}$ & $1.93^{\mathrm{b}}$ & 0.02 \\
\hline Small intestine & $1.27^{\mathrm{a}}$ & $0.73^{\mathrm{b}}$ & $0.71^{\mathrm{b}}$ & $0.70^{\mathrm{b}}$ & 0.24 \\
\hline Large intestine & $1.64^{\mathrm{a}}$ & $0.95^{\mathrm{b}}$ & $0.92^{\mathrm{b}}$ & $0.91^{\mathrm{b}}$ & 0.16 \\
\hline
\end{tabular}

a,b,c Means in the same row with varying superscript differ significantly $(\mathrm{P}<0.05) \mathrm{SEM}=$ Standard error of mean,

Indicated in Table 7 is the economic analysis of sheep on diets containing cabbage and carrot wastes. Cost of sheep, total fixed cost and total cost had higher values in control diet than the test diets. Remarkable differences in sales of sheep, total revenue and net profit were more pronounced for diets with cabbage waste than other diets. Feed cost and total variable costs registered higher values in sheep on diet with carrot waste as compared with diet contained cabbage waste and control group. 
World Journal of Advanced Research and Reviews, 2021, 12(02), 574-586

Table 7 Economics efficiency of feeding diets containing cabbage and carrot wastes to sheep

\begin{tabular}{|c|c|c|c|c|c|}
\hline \multirow[t]{2}{*}{ Item (Naria/animal) } & \multicolumn{5}{|c|}{ Treatment Diets } \\
\hline & TD $_{1}$ & $\mathbf{T D}_{2}$ & $\mathbf{T D}_{3}$ & TD $_{4}$ & SEM \pm \\
\hline \multicolumn{6}{|l|}{ Fixed Cost } \\
\hline Depreciation of equipment & 2000 & 2000 & 2000 & 2000 & 0.01 \\
\hline Depreciation of pen & 3000 & 3000 & 3000 & 3000 & 0.02 \\
\hline Labour & 4000 & 4000 & 4000 & 4000 & 0.01 \\
\hline Cost ofsheep & $70,000^{\mathrm{a}}$ & $47,000^{c}$ & $60,000^{\mathrm{b}}$ & $63,000^{\mathrm{b}}$ & 0.86 \\
\hline Transportation & 2,500 & 2,500 & 2,500 & 2,500 & 0.02 \\
\hline Total fixed costs (TFC) & $81,500^{a}$ & $58,500^{c}$ & $71,500^{\mathrm{b}}$ & $74,500^{\mathrm{b}}$ & 0.92 \\
\hline \multicolumn{6}{|l|}{ Variable Cost } \\
\hline Utility Cost & 1,675 & 1,675 & 1,675 & 1,675 & 0.87 \\
\hline Veterinary drugs & 1,500 & 1,500 & 1,500 & 1,500 & 0.01 \\
\hline Feed cost & $6,200^{\mathrm{b}}$ & $5,600^{c}$ & $7,200^{\mathrm{a}}$ & $7,500^{\mathrm{a}}$ & 0.62 \\
\hline Total variable costs (TVC) & $9,375^{b}$ & $8,775^{c}$ & $10,375^{\mathrm{a}}$ & $10,675^{\mathrm{a}}$ & 0.75 \\
\hline Total cost (TC) & $90,875^{a}$ & $67,275^{c}$ & $81,875^{b}$ & $85,175^{b}$ & 0.98 \\
\hline \multicolumn{6}{|l|}{ Revenue } \\
\hline Sales of sheep & $150,000^{c}$ & $180,000^{a}$ & $172,000^{\mathrm{b}}$ & $170,000^{\mathrm{b}}$ & 0.97 \\
\hline Sales of litter & 5,625 & 5,625 & 5,625 & 5,625 & 0.01 \\
\hline Total revenue (TR) & $155,675^{c}$ & $185,625^{\mathrm{a}}$ & $177,625^{b}$ & $175,625^{b}$ & 0.86 \\
\hline Net profit (NP) & $64,800^{c}$ & $118,350^{a}$ & $95,750^{\mathrm{b}}$ & $90,450^{\mathrm{b}}$ & 0.79 \\
\hline
\end{tabular}

\section{Discussion}

As showed in Table 1 is the chemical composition of feed ingredients used in the study. Their dry matters were quiet high, indicating good nutrient retention in the feed ingredients. It is of interest to note that crude protein values registered in the feeds with exception of carrot waste were higher than the critical level of $8 \%$ requirement for minimum performance of sheep and goats [15]. The lower crude fiber content recorded in concentrate ration was expected, since concentrate diets were met to augment the nutrient content of high fibre feeds. Guinea grass values recorded were comparable with the range values reported in literature by Okoruwa [16].

Table 2, presents the chemical composition of the experimental diets of sheep. The examined crude protein content in the study fell within the CP requirement of $15-18 \%$ for growing lambs with weight range of $10-30 \mathrm{~kg}$ [17]. However, the crude fiber values that that ranged from 23.65 to $26.52 \%$ was adequate for the requirement of growing sheep as noted by Fadiyimu et al., [18] when they estimated the crude fiber requirement of ruminants to be $22 \%$ to $25 \%$. Generally, the observed variation in nutrient content for treatment diets could probably due to the reflection of different plant components that supplied nutrients to the diets.

It is worth mentioning that the higher total and daily dry matter intake obtained in diets with cabbage and carrot wastes suggest that the test ingredients did not inhibit voluntary feed intake by sheep. This phenomenon could be related to the physical nature and increased in palatability of the diets that present readily available nutrient which has been found to be associated with increase in feed intake of ruminants. Hassan et al. [4] reported that increased in feed consumption and nutrient availability of a diet can be attributed to its nature and palatability that show positive change in performance of ruminants. The discrepancy observed in final and total weight gain at similar growth stage of sheep in this study could be mainly influenced by the difference in dietary components and nutrient utilized by the sheep. However, results obtained in feed intake in relation to weight gain reviled better feed conversion ratio capacity of the 
test diets that were more efficiently utilized by sheep which have accounted for superior growth performance. The total weight gains recorded in this finding were higher than average value of $41.84 \mathrm{~g} /$ day reported by Okoruwa [2] for sheep on ginger powder and lime peel supplementation.

Dry matter digestibility is noted in literature [19] to depend on the cell wall constituents of a diet. Hence the low dry matter digestibility co-efficient observed for sheep on control group could probably explained by the poor interactive effect of feed constituents that affected the digestion activity. Meanwhile, the improvement of dry matter digestibility noted in the test diets could probably responsible for the higher crude protein digestibility in the treatment effects. This is in consistency with the report of Saman et al. [20] that many factors governing the digestibility of feeds include; the quality of feeds, amount of dry matter consumed, feed flow rate on the gastrointestinal tract and manner of rumen fermentation. Crude fiber is the portion of the diet that is poorly digested in the gut with prolonged retention time in the rumen. The digestibility of crude fiber and its fractions in this current study were improved in diets with cabbage and carrot wastes supplementation. .The increased intake and passage rate of nutrients in response to the increase of the available of phytogenic supply in the rumen by the test ingredients could possibly had the positive effect on the digestibility. The improved ash and nitrogen free extract digestibility noted in the test diets could related to their easily digestible quality which influenced the activities of degrading microbes in the rumen. Higher digestibility of nutrients obtained in the study further affirmed the observation of Okoruwa [16] that plant leaves supplementation in ruminant diets brings about increment in nutrient supply that account for better digestibility of nutrients. However, no effect was seen from the levels of test ingredients on ether extract digestibility, this was expected as they contributed less oil to the diets.

Blood profile as presented in Table 4, is an important index in evaluating feeds and their effects on health status of animals. However, it appears that diets contained cabbage and carrot wastes were directly increased the metabolic efficiency of sheep which could possibly reflected in their higher values obtained in haemoglobin (Hb), packed cell volume ( PCV) and red blood cell (RBC). As reported previously [4], that higher significant values of haematological indices are good indication for normal healthy conditions with physiological sound that result from good nutritional quality and absence of toxic substance in feeds. Interestingly, values of Hb, PCV and RBC observed in this study were positively comparable with the normal range of values reported by most studies [20,21]. The similarities that exist in values of mean corpuscular volume (MCV) and mean corpuscular haemoglobin concentration (MCHC) indicates that $\mathrm{Hb}$, PCV and RBC in sheep could be classified as normal, suggesting the suitability and superiority of the feeds. The nutritional adequacy and safety of test diets further attributed to the improve values recorded in mean corpuscular haemoglobin (MCH) which showed sheep resistance to diseases. White blood cell (WBC) explained that the test diets improved immune system, anti - body's production and disease fighting ability of sheep. It was apparent that addition of bioactive components in the test diets could probably be the reasons for this divergent result in sheep. Notwithstanding, similar result was reported by Okoruwa and Edoror [19] who noted that nutritional quality of goat is not altered by Garcinia kola seed meal inclusion in the diet but intend to increase the WBC of goats. The differentials of WBC counts are possible indicators of health problems in an animal. The considerable increased in lymphocyte and neutrophil values in diets with cabbage waste implies that sheep on these treatments had the tendency of not being susceptible to microbal infection. Though monocyte and basophil presence in the blood are indication of disease conditions and blood inflammation. Their levels obtained did not point any danger since, they are still within the normal range of $40-75 \%$ lymphocytes, $10-50 \%$ neutrophil, $1-5 \%$ monocytes and $0-3 \%$ basophil as expressed by [9]. Eosinphil is also noted by Jain [9] to be an indication of parasite infection that resulted from the foreign substance introduced into the body by feeds. However, their low values observed in the sheep blood which fell within the reported range of $1-8 \%$ [9] was an indication that the sheep immune system was not challenged by any toxic substance in the feeds.

Table 4 also showed the serum biochemical parameters of sheep consuming experimental diets. The marked increased observed in serum total protein, albumin, implies that the test diets were able to supply adequate amount of protein that offered available nitrogen for rumen microbes and consequently enhanced protein absorption in the intestine that was needed to maintain normal serum protein levels in sheep. The serum protein levels observed in this study were valuable in reflecting the health of hepatic cells of sheep, indicating no anti-nutritional factors in the diets that could reduce absorption. Furthermore, it is important to know that the soluble carbohydrates and digestible nutrients in the test diets was associated with the increased in blood glucose, cholesterol and triglyceride concentration which was generally proportional to the increment of body weight gain (Table 4). This reason explains the presence of optimum quality of feeds that could directly increased metabolic efficiency and modulate the nutritional metabolism that interfered with growth characteristics and suitable health status [10]. Serum urea and creatinine are known to be function of protein quality digested by animal; they are indirect measure of availability and optimum utilization of protein. The low result observed in urea and creatinine values could principally suggest adequacy of protein utilization and consumed reduction in tissue wastage in the sheep [22]. 
Weight at slaughter is an important economic trait that determines market value of a meat type of sheep. However, Sheep on diets with cabbage inclusion exhibited higher slaughter and hot carcass weight (Table 5). This is expected as sheep weight could probably be influenced by efficient utilization of the test diets. This explanation is collaborated with the report of Okoruwa and Edoror [23], that sex, environment, age of development and efficiency of feeding are identify as major determinant of carcass quality. The similar dressed carcass percentage obtained in test diets, despite their difference in body weight at slaughter could be due to relatively higher dressing loss of the sheep. The dressing percentage values of this current study corresponded with the average value of $48.59 \%$ earlier reported for sheep by Okoruwa and Edoror [23]. This increased dressing percentage reflection of sheep on test diets were also noticed in the higher positive turned out of neck, rack and liver. The similarity observed in the internal organs like thorax, heart, liver and kidneys among the treatments explained how safeties and less toxic were test feeds.

Edible offal (Table 6) is important component of carcass traits that is included in edible portion of sheep meat by most of Nigeria consumers. However, the correlation between improved weight of head, lungs, testis as well as skin and dressing percentage could probably responsible for increased total weight again observed per sheep (Table 3). Thus, higher body weight at slaughter would attribute to higher meat yield. The higher relative organ weight of rumen and intestine found in sheep on control group were connected with the higher fiber content in the diet. This is similar to the work of Elias et al. [11] who observed that feeding higher fiber diets to sheep enhance relative length with weight of intestine and sizes of various digestive components, resulting in decrease dressing percentage. The similar weight of trachea, blood, gall bladder, spleen and trotter obtained in the study might be traced to the age of the sheep that were close in range. This fact is in accordance with the view of Elias et al. [11] that some relative organs in ruminants are associated priority of age rather than dependently of feeding.

Though, it would not be ideal to fully explain the economic efficiency of feeding sheep (Table 7) on the basis of their net profit, without other factors such as wool and farm sizes. However, it might give a rough idea about the income of the sheep. The results of an attempt to compare the total cost and net profit of sheep using their performance under intensive condition clearly showed that there were great variations among sheep on dietary treatments. According to the values obtained using market prices, sheep on cabbage waste supplement were quite better in performance and generated higher net profit than other sheep. The significant lower total cost per sheep on diets with cabbage waste in this study corroborates Adegun and Aye [24] work on sheep. This explains that each kilogram of weight gain of sheep at higher levels of cabbage waste inclusion in diets would be produced at a lower cost, thus suggesting higher efficiency in production with revenue and profit yields. Most studies have suggested that plant leaf and tree foliage are costeffective nutrient sources that can be used in ruminant feeding [24, 25].

\section{Conclusion and Recommendation}

Results of this study discovered that the inclusion of cabbage and carrot wastes as supplement up to $10 \%$ levels in the basal diet of $50 \%$ guinea grass and $40 \%$ concentrate had no adverse effect on nutritional status; but improved the performance, health status and carcass indices of sheep. However, this supplementation at this level was more enhanced with reduced cost of production per kilogram of weight gain, resulting in higher profit of sheep, when $50 \%$ guinea grass with $40 \%$ concentrate with $10 \%$ cabbage waste . $\left(\mathrm{TD}_{2}\right)$ was used in the treatment diet. Therefore, it will be better for $\mathrm{TD}_{2}$ to be adopted, if productivity and profitability enhancement is our goal.

\section{Compliance with ethical standards}

\section{Acknowledgments}

This work was supported by Faculty of Agriculture Teaching and Research Farm, Ambrose Alli University, Ekpoma Nigeria.

\section{Disclosure of conflict of interest}

None.

\section{Statement of ethical approval}

The present research work does not contain any studies performed on animals/humans subjects by any of the authors. 


\section{References}

[1] Lawal-Adebowale O. Dynamics of ruminant livestock management in the context of Nigerian agricultural system. Livestock Production. 2012; 4: 1 - 20.

[2] Okoruwa MI, Aidelomon EO. Manipulation of rumen fermentation and microbial diversity for live-weight gains of sheep as influenced by ginger powder and lime peel. European Journal of Biology and Biotechnology.2020; 1(5): $1-6$.

[3] Al-Azazi ASH, Baraka TA, Khalaf AM. Effect of ginger powder (Zingiber officinale) on selected rumen and blood serum constituents in sheep. Indian Journal of Applied Research. 2018; 8(4): 450 - 457.

[4] Hassan TMM, Abdel-Fattah FAI. Farid AS, Kamel ER. Effect of feeding guava waste on growth performance, diet digestibility, carcass characteristics and production profitability of ossimi lambs. Egyptian Journal of Nutrition and Feeds. 2016; 19(3): $463-475$.

[5] Adanma CI, Ugochi CO. Quality evalution of tea brewed from blends of soursop (Annona muricata) and moringa (Moringa oleifera) leaves. European Journal of Nutrition \& Food Safety.2019; 10(1): 1-15.

[6] FAO. Commodity Review and Outlook. Source: UNCTAA from Food and Agricultural Organisation Data. Rome Italy. 2004; 42-55.

[7] McDonald PRA, Edward JFD, Greenhaigh, Morgan GA. Animal Nutrition $6^{\text {th }}$. Ed. Pearson Eductional Limited Edinburgh. Great Britain.2002; 544.

[8] Coles EH. Veterinary clinical pathology (4th edition) W B Saunders Company, Philadelphin. Harcourt Brace Jovarinch Inch. 1986.

[9] Jain NC. Essentials of veterinary haematology. Len and ferbeiger, Pennsylvania, USA. $1993 ; 7$.

[10] Kim SH, Alam MJ, Gu MJ, Park KW, Jeon CO, Ha JK, Cho K K, Lee SS. Effect of total mixed ration with fermented feed on ruminal in-vitro fermentation, growth performance and blood characteristics of Hanwoo steers. Asian Auustralas Journal of Animal Science. 2012; 25(2): 213 - 223.

[11] Elias AK, Laves KS, Liberal-Vera RM, Oliveral LRS, Mezzomo R, Curtin DO. Carcass and non-carcass characteristics of sheep fed well cassia seed meal based diet. African Journal of Agricultural Research. 2015; 10 (49); 4395 4399.

[12] AOAC.Official Methods of Analysis. Association of official analytical chemist, 15 $5^{\text {thEdition (Khelrick, editor) }}$ Arlington. 19901230.

[13] Van Soest PJ, Wine RH. Use of Detergent in the Analysis of Fibrous Feeds. IV. Determination of Plant Cell-Wall Constituents. Journal of the Association of Official Analytical Chemists. 1967;50: 50-55.

[14] Statistical Analysis System (SAS). User's Guide: version 9.2. SAS Institutres Inc. Cary, NC, USA. 2009.

[15] NRC (National Research Council). Nutrient requirements of beef cattle. $7^{\text {th }}$ Revised edition. National Academy Press. Washington DC. 1996; 23.

[16] Okoruwa, M. I. Feed intake, relative preference index, rumen digestion kinetics, nutrient digestibility and live weight change of goats fed selected browse plants. Livestock Research for Rural Development.2019.

[17] ARC. The nutrient requirement of ruminant livestock. Supplement 1. Agricultural Research Council, Commonwealth Agricultural Bureaux, Farham Royal, UK, 1990; 78 - 80.

[18] Fadiyimu AA, Alokan JA, Fajemisin AN, Onibi GE. Feed intake, growth performance and carcass characteristics of West African dwarf sheep fed Moringa oleifera, Gliricidia sepium or cassava fodder as supplements to Panicum maximum. Journal of Experimental Agriculture International. 2016; 14 (4); 1-10

[19] Okoruwa MI, Edoror OM. Effects of garlic oil supplementation on intake, digestibility, and performance and rumen functions of goats fed silage based-diets. European Journal of Nutrition and Food Safety. 2019; 10(2); 104 -115 .

[20] Saman L, Akbu T, Hamid P, Soren KJ. Growth performance, nutrient digestibility and blood parameters of fattening lambs fed diet replacing corn with orange pulp. Spanish Journal of Agricultural Research. 2017;15(1) e06sco1, 7. 
[21] Aruwayo A, Maigandi SA, Malami BS, Daneji AI. Haematological and Biochemical parameters of uda lambs fed graded levels of alkali-treated neem kernel cake. Nigeria Journal of Basic and Applied Science. 2011;19 (2); 277284.

[22] Chen GJ, Song SD, Wang BX, Zhang ZF, Peng ZI, Guo CH, Zhong JC, Wang Y. Effects of forage: Concentrate ratio on growth performance, ruminal fermentation and blood metabolites in housing- feeding Yaks. Asian Auustralas Journal of Animal Science. 2015; 28(12); 1736 - 1741.

[23] Okoruwa MI, Edoror OM. Effect of lemon grass powder on performance, carcass and meat quality characteristics of goats fed cassia seed meal. International Journal of food science and Nutrition. 2021; 6(2); 120 - 127.

[24] Adegun MK, Aye PA. Growth performance and economic analysis of West African dwarf rams fed Moringa oleifera and cotten seed cake as protein supplements to Panicum maximum. American Journal of Food and Nutrition. $2013 ; 3(2) ; 58-63$.

[25] Yusuf AO, Miambo V, Iposu SO.Nutritional and economic evalution of Moringa oleifera leaf meal as a dietary supplement in West African goats. South African Journal of Animal Science. 2018; 48 (1); 81 - 87 